\title{
Shiraliyeva N.A.
}

DOI: 10.25108/2304-1730-1749.iolr.2018.54.249-261

\section{A system of the principles of international law}

Abstract: Until now there is no response concerning a content of the categories "universally recognized principles and norms of international law" in the acts of an official interpretation. In result of such uncertainty the links in legal system are formed without well justification, and a law enforcement official comes in a difficult position concerning the fact what act and in what form and when to adopt, prepare and apply.

Keywords: international law; principles; universally recognized norms; state; cooperation.

It has historically turned out a few forms of expression of universally recognized principles and norms of international law. International legal practice and international treaty are recognized the main among them [4, p. 49-61].

With respect to the practice as a source of international law S.I. Victorsky well-focused in 1912: "Presently practice, we may say, went away in a field of history and applied only in time of handling the cases in far periphery of the state, in the basis of the fact that indigenous people, tribes, which are on the lowest level of development, cannot be required that they are guided with norms of written material and procedural law in their daily life... Though written laws are less movable than common law, but they provide the best guarantees against arbitrariness of judges and introduce a full certainty in court proceedings that is why presently they are almost exclusively as a source of procedural law" $[3$, p. 76 ; 77].

\footnotetext{
- Shiraliyeva Narmina Azer qizi - a member of International Organization for Legal Researches, the Western University (Azerbaijan). E-mail: mopi_sid@yahoo.com
} 
At the same time, according to G.M. Danilenko, a head of the Centre for international law of the Institute of State and Law of Russian Academy of Sciences, traditionally an issue of establishing of presence and accurate normative content of "universally recognized principles and norms of international law" is a subject of numerous debates even among the specialists on international law. It justified with presence of a wide divergence of views on a core of the definition "universally recognized principles and norms of international law" in foreign literature [9, p. 139].

Until 1984 in virtue of primacy the politics over the law the definition "universally recognized principles of international law" was not long time a subject of studies in legal literature [12, p. 139]. The last years the problem, gaining more significance for the both the common theory of law and other fields of law, is developed, actually, only in frames of science of international law [5, p. 221]. This is precisely why the first monograph investigation "Universally recognized norms in modern international law" appeared only in the mid-1980-s [8, p. 25]. In this connection, it seems justified to refer the following signs of the universally recognized norms, highlighted in this work:

- like any norm of international law, universally recognized norm is a rule of behaviour, content of which established in result of alignment of the wills of the states and which adopted by them as such in the basis of their own command;

- universally recognized norms are the norms of law, common for the states of various socio-economic systems which presupposes a representative recognition the norms by the states belonging to different socio-economic systems;

- universally recognized norms are the elements of those legal system, which cover or should cover all states. These norms are common for all states of international law, universally applied to all these states. Universal assignment and universal admissibility of the universally recognized norms have determined by total interest - total interest of the states in legal fixation of common acceptable 
decision permanent growing of number of problems touching the interests of mankind and requiring participation of maximum wide circle of the states for its solution [8, p. 25].

In light of these signs it was formulated the following definition: universally recognized norm is a rule of behaviour that fixes archived level of cooperation of the states, their universal concern in solution of urgent problems and recognized as universal by all or the most part of the states, which are presented various socioeconomic systems [8, p. 25]. Applied to this definition in science of international law the concepts of principle and norm became to be used as an equivalent $[14, \mathrm{p}$. 324].

In given definition is made an emphasis to the fact that to universally recognized norms on human rights might be related only universal for all states the norms, rules of behaviour. This conclusion is very important due to the fact that in acting area the international norms concerning human rights might be local (including regional), i.e. acting or aimed to be applied in limited number of states [6, p. 168]. Thus, in a base of scientific search of those acts, which contain universally recognized international norms on human rights, should be put a sign of their universality.

A former chair of the UN Commission on Human Rights A. Agillara noted on this matter that "Universal Declaration on Human Rights and international pacts contain the norms, which distinguished from the collective experience and common heritage all people of the world, present to be universal standards of behaviour for all people and states" [16, p. 56].

In such situation of multi-variant approach to problem it should be recognized as logic an attempt to find its solution through the search of indications onto universal sources of universally recognized norms, which contain in international legal documents. The first document, which has direct indication to the source of universally recognized principles of international law, should relate Vienna 
Convention on the Law of Treaties of 1969. This Convention, which has its purpose to characterize the legal force of those or other commonly-recognized norms, with Article 52 establishes that quality of imperative nature has "the principles of international law embodied in the Charter of the United Nations" [2, Art. 772]. Main principles stipulated the UN Charter is characterized by the scientists of international affairs as "basic rules" [1, p. 73], "fundamental important principles, the internal basis of the whole system of international law" [13, p. 83], "a core of modern international law" [15, p. 171].

In developing of friendly relations, in compliance with the UN Charter, the universally recognized principles were detailed by the states with number of more special norms in Declaration on principles of international law of 1970 [10, p. 460469]. At last, final agreed understanding of universally recognized principles was given by international community in Final Act of the Conference on Security and Cooperation in Europe of 1975, in its integral part - Declaration of principles [11, p. 24].

Thus, universally recognized principles of international law are fixed in the three different sources: in the UN Charter, Declaration on principles of international law of 1970 and Final Act of the Conference on Security and Cooperation in Europe of 1975. Despite this universally recognized principles have a sign of interrelation. So, Declaration on principles of international law of 1970 says that "in their interpretation and application the above principles are interrelated and each principle should be construed in the context of the other principles" [7, p. 2-8]. Likewise, the Final Act underlines that stipulated principles will be "applied at interpretation each of them with considering others" [7, p. 8$12]$.

Content of principles of international law of 1970 and the Final Act of the Conference on Security and Cooperation in Europe of 1975 allows referring the following universally recognized principles of international law to number of 
interrelated: the principle of peaceful coexistence, refrain in their international relations from the threat or use of force, not to intervene in the affairs of any other State, peaceful settlement of international disputes, inter-state cooperation, equal rights and self-determination, sovereign equality of states, fulfillment in good faith the obligations assumed by them, respect of human rights and freedoms of man.

\section{References}

1. Bobrov R.L. Sovremennoe mezhdunarodnoe pravo (ob'ektivnye predposylki i sotsial'noe naznachenie) [Modern international law (objectives preconditions and social assignment)]. Leningrad, 1962, $231 \mathrm{p}$.

2. Vedomosti Verkhovnogo Soveta SSSR [Bulletin of the Supreme Council of USSR], 1986. No. 37. Art. 772.

3. Viktorsky S.I. Russkiyi ugolovnyi protsess [Russian criminal process]. Uchebnoe posobie [Tutorial]. Moscow, 1997, 448 p.

4. Danilenko G.M., Charni J.I. Sozdanie mezhdunarodnogo prava i soglaisie gosudarstv [Creation of international law and consent of states] // Vne konfrontatsii. Mezhdunarodnoe pravo $\mathrm{v}$ period kholodnoyi voyiny [Out of confrontation. International law in period after cold war]: Sbornik stateyi [Collection of articles]. Moscow, 1996, pp. 49-61.

5. Zivs S.L. Istochniki prava [Sources of law]. Moscow, 1981, 239 p.

6. Zimin V.P Universal'nye i obscheevopeyiskie normy, kasayushiesya prav cheloveka $\mathrm{v}$ sfere okhrany pravoporyadka [Universal and all-European norms relating human rights in an area of protection of law and order] // Problemy obespecheniya prav cheloveka v deyatel'nosti organov vnutrennikh del [Problems of ensuring human rights in activity of internal affairs bodies]. Sbornik stateyi [Collection of articles]. Moscow, 1994. 
7. Mezhdunarodnoe publichnoe pravo [International public law]. Sbornik dokumentov [Collection of documents]. Vol. 1. Moscow, 1996, 539 p.

8. Obschepriznannye normy $\mathrm{v}$ sovremennom mezhdunarodnom prave [Universally recognized norms in modern international law]. Kiev, 1984, 269 p.

9. O primenenii norm mezhdunarodnogo prava pravookhranitel'nymi organami Rossiyiskoyi Federatsii [On application of the norms of international law by law enforcement bodies of Russian Federation] (Obzor materialov nauchnoprakticheskoyi konferentsii [Review of materials of Sci.-Prac. Conf.]) // Gosudarstvo i pravo. 1996, no. 5.

10. Organizatsiya Ob'edinennykh Natsiyi [United Nations]. Sbornik dokumentov [Collection of documents]. Moscow, 1981, pp. 460-469.

11. Prava cheloveka [Human Rights]. Sbornik universal'nykh i regional'nykh dokumentov [Collection of universal and regional documents] / Sost. L.N. Shestakov.

12. Pravo i politika sovremennoyi Rossii [Law and politics of modern Russia]. Moscow, 1996, 216 p.

13. Pushmin E.A. O ponyatii osnovnykh printsipov sovremennogo mezhdunarodnogo prava [On concept of basic principles of international law] // Sovetskyi ezhegodnik mezhdunarodnogo prava, 1978. [Soviet yearbook of international law]. Moscow, 1986, 289 p.

14. Slovar' mezhdunarodnogo prava [Dictionary of international law]. Moscow, 1986, 432 p.

15. Talalaev A.N. Yuridicheskaya priroda mezhdunarodnogo dogovora [Legal nature of international treaty]. Moscow, 1963, 263 p.

16. Ramcharan O. The Concept and Present Status of International Protection of Human Rights: Forty Years after Universal Declaration - Dordrecht, 1989. 